\title{
Celebrating a quarter century of the Injury Free Coalition for Kids ${ }^{\circledR}$
}

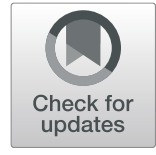

\author{
Lois K. Lee ${ }^{1,2}$
}

From 24th Annual Injury Free Coalition for Kids Conference: Forging New Frontiers: Motor Vehicle Safety for All Ages

Fort Lauderdale, FL, USA. 06-08 December 2019

"We choose to go to the moon in this decade and do the other things, not because they are easy, but because they are hard, because that goal will service to organize and measure the best of our energies and skills, because that challenge is one that we are willing to accept, one we are unwilling to postpone, and one which we intend to win." -- John F. Kennedy.

This year we celebrate the 25th anniversary of the Injury Free Coalition for Kids ${ }^{\circ}$. Although we are commemorating this anniversary in 2020, the Injury Free story really began in 1981 when Dr. Barbara Barlow, founder of the Injury Free Coalition for Kids ${ }^{\circ}$, established the Injury Prevention Program at Harlem Hospital in New York City, NY. This Program instituted a populationbased pediatric injury surveillance system in Harlem to identify the leading mechanisms of injury for children and youth in this area to inform and evaluate injury prevention efforts (Durkin et al., 1994). Based on this initial work, in 1988 the Robert Wood Johnson Foundation (RWJF) provided a 3-year grant to further establish and develop the Harlem Hospital Injury Prevention Program (HHIPP) (Pressley et al., 2005). Initiatives implemented by the HHIPP during this time included window guard campaigns; the Kids, Injuries and Street Smarts (KISS) Program; Burn Prevention Curriculum and Smoke Detector Distribution; Harlem Alternative to Violence Program; Critical Incident Stress Management Teams; youth sports programs; and the Greening of Harlem Program. In addition to these programs, Dr. Barlow and

\footnotetext{
Correspondence: Iois.lee@childrens.harvard.edu
'Division of Emergency Medicine, Boston Children's Hospital, Boston, MA,

Correspondence: lois.lee@childrens.harvard.edu
'Division of Emergency Medicine, Boston Children's Hospital, Boston, MA, USA

${ }^{2}$ Departments of Pediatrics and Emergency Medicine, Harvard Medical School, Boston, MA, USA
}

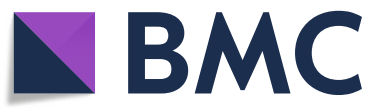

(C) The Author(s). 2020 Open Access This article is licensed under a Creative Commons Attribution 4.0 International License, which permits use, sharing, adaptation, distribution and reproduction in any medium or format, as long as you give appropriate credit to the original author(s) and the source, provide a link to the Creative Commons licence, and indicate if changes were made. The images or other third party material in this article are included in the article's Creative Commons licence, unless indicated otherwise in a credit line to the material. If material is not included in the article's Creative Commons licence and your intended use is not permitted by statutory regulation or exceeds the permitted use, you will need to obtain permission directly from the copyright holder. To view a copy of this licence, visit http://creativecommons.org/licenses/by/4.0/ The Creative Commons Public Domain Dedication waiver (http://creativecommons.org/publicdomain/zero/1.0/) applies to the data made available in this article, unless otherwise stated in a credit line to the data.
B, "build a coalition" by engaging the local community to understand and respond to the problems C, "communicate the problem" to educate political leaders and the community about pediatric injuries D, "develop the interventions" to decreased injuries to community children the HHIPP innovatively worked to eliminate unsafe ment (Laraque et al., 1995).

Based on the successful work of the HHIPP, the RWJF funded a 3-year "replication program" in 1995 to expand Atlanta, GA, Chicago, IL, Kansas City, MO, Los Angeles, $\mathrm{CA}$, and Pittsburgh, PA. None of these cities had population-based injury surveillance systems or active injury prevention programs at that time. In 1997, this multi-site injury prevention initiative was given the (n) "Injury Free Coalition for Kids.". Then in 2001 Injury Free Coalition for Kids ${ }^{\circ}$ has sites at over 40 insti(Pressley et al., 2005)

We have included two seminal articles related to the establishment of Injury Free in this edition of Injury EpiThese programs were developed on the foundations of Injury Free's ABC's of injury prevention model: 
E, "evaluate the programmatic efforts" to evaluate the impact of the interventions (Pressley et al., 2005).

These principles continue to guide the Injury Free sites as they work to prevent injuries in their communities and nationally.

As we celebrate the 25th anniversary of the Injury Free Coalition for Kids, we also want to remember Dr. Joseph J. Tepas, III, who died on December 20, 2019. Dr. Tepas was a pediatric surgeon and a leader in the field of pediatric trauma. He was instrumental in founding the first pediatric-specific national trauma registry, the $\mathrm{Na}$ tional Pediatric Trauma Registry. He served as the supplement editor for the annual Injury Free meeting proceedings published in the Journal of Trauma and Acute Care Surgery from 2007 to 2017. Publication of this meeting supplement, now in Injury Epidemiology, continues to be an important venue for demonstrating and disseminating our injury prevention work and research. We honor his unmeasurable contributions to improving the lives of children and are grateful for all his service as a member and editor for the Injury Free Coalition for Kids ${ }^{\circ}$.

Visionaries like Dr. Barlow and Dr. Tepas have made a difference in the lives of innumerable children and families as they have forged new frontiers in pediatric trauma care and injury prevention. They did not choose this path because it was easy, but because it was hard, and because they it was one they were unwilling to postpone. After 25 years their work has accomplished a great deal, but there is still much to be done. And the Injury Free Coalition for Kids ${ }^{\otimes}$ continues to accept this challenge, knowing it is not easy, but that it is hard. Because our goal is not the "moon," but for our children to leave in a world that is Injury Free.

\section{Acknowledgements}

Not applicable.

\section{About this supplement}

This article has been published as part of Injury Epidemiology Volume 7 Supplement 1, 2020: Proceedings from the 24th Annual Injury Free Coalition for Kids ${ }^{\circledast}$ Conference: Forging New Frontiers: Motor Vehicle Safety for All Ages. The full contents of the supplement are available online at https:// injepijournal.biomedcentral.com/articles/supplements/volume-7supplement-1.

\section{Author's contributions}

$\mathrm{LKL}$ conceived and wrote this manuscript. The author read and approved the final manuscript.

\section{Funding}

Publication of this article was funded by the Injury Free Coalition for Kids ${ }^{\circledR}$.

Availability of data and materials

Not applicable.

Ethics approval and consent to participate Not applicable.
Consent for publication

Not applicable.

Competing interests

The author has no conflicts of interest to declare.

Published: 12 June 2020

References

Durkin MS, Davidson LL, Kuhn L, O'Connor P, Barlow B. Low-income neighborhoods and the risk of severe pediatric injury: a small- area analysis in northern Manhattan. Am J Public Health. 1994;84(4):587-92. https://doi. org/10.2105/AJPH.84.4.587.

Laraque D, Barlow B, Durkin M, Heagarty M. Injury prevention in an urban setting: challenges and successes. Bull N Y Acad Med. 1995;72(1):16-30 EBSCOhost.

Pressley JC, Barlow B, Durkin M, Jacko SA, Dominguez DR, Johnson L. A national program for injury prevention in children and adolescents: the injury free coalition for kids. J Urban Health. 2005;82(3):389-402. https://doi.org/10.1093/ jurban/jti078.

\section{Publisher's Note}

Springer Nature remains neutral with regard to jurisdictional claims in published maps and institutional affiliations. 